\title{
THE POSSIBILITY OF IN VITRO MULTI-ENZYMATIC METHOD APPLICATION FOR THE ASSESSMENT OF THE INFLUENCE OF THERMAL TREATMENTS ON ORGANIC MATTER DIGESTIBILITY OF FEED FOR RUMINANTS
}

Bojana M. Kokić ${ }^{1}$, Ljubica P. Dokić ${ }^{2}$, Radmilo R. Čolović ${ }^{1}$, Vojislav V. Banjac ${ }^{1}$, Rade D. Jovanović ${ }^{3}$, Sanja J. Popović ${ }^{1}$, Jasmina M. Lazarević ${ }^{1}$

${ }^{1}$ University of Novi Sad, Institute of Food Technology, 21000 Novi Sad, Bulevar cara Lazara 1, Serbia

${ }^{2}$ University of Novi Sad, Faculty of Technology, 21000 Novi Sad, Bulevar cara Lazara 1, Serbia

${ }^{3}$ Institute for Science Application in Agriculture, 11000 Belgrade, Bulevar despota Stefana 68b, Serbia

\author{
${ }^{*}$ Corresponding author: \\ Phone: +381214853828 \\ Fax: +38121450725 \\ E-mail address: bojana.kokic@fins.uns.ac.rs
}

\begin{abstract}
In vitro multi-enzymatic method is a two-step procedure that uses exogenous enzymes for incubation of feed that aim to imitate digestive processes in the animal. It is used for determination of organic matter digestibility (OMD) of various feedstuffs and complete mixtures used in ruminant nutrition. The aim of the present work was to determine whether this in vitro multi-enzymatic method can be applied for the assessment of the influence of thermal treatments on OMD of feed for ruminants. Samples of corn and complete mixture for cows (based on corn) were subjected to pelleting, steam flaking, micronization and extrusion. Statistical analysis of the results did not show significant increase of corn and complete mixture OMD after various thermal treatments compared to untreated samples, which can be explained by high digestibility of corn itself (exceeds $90 \%$ ). Based on obtained results it can be concluded that applied in vitro method is not suitable for the assessment of the influence of thermal treatments on OMD of corn and corn based mixture, while future research should be broadened to analysis of samples with lower OMD, such as sorghum, oats and barley.
\end{abstract}

Key words: organic matter digestibility, ruminant, corn, thermal treatment

\section{INTRODUCTION}

Animal feed is analyzed in order to obtain information on its value as a source of nutrients. When there is a possibility in vivo measurements are performed, but it requires animals, relatively large amount of feed and time for testing. In vivo measurements are expensive, and in addition, it is necessary to invest intensive work that does not make them suitable for routine analysis. A possible solution to this problem is fast and cheap laboratory methods for routine prediction of in vivo organic matter digestibility (OMD) in ruminant nutrition. There are several laboratory procedures that are used to predict OMD of feed for ruminants, that are based on chemical analysis or biological methods that simulate the digestion process. Getachew et al. (1998) list three major digestion techniques (biological methods) currently available for determining the nutritional value of ruminant feeds: 1 ) digestion with rumen 
microorganisms, 2) hydrolysis with enzymatic preparations, 3) in situ incubations of samples in nylon bag in the rumen.

In vitro techniques are based on the incubation with a microbial inoculum from the rumen which is used as a digestive medium. According to Gosselink et al. (2004) most accepted in vitro techniques are Tilley and Terry method (Tilley and Terry, 1963) and gas production technique developed by Menke and Steingass (1988). The disadvantages of the aforementioned methods arise from the problems associated with inoculum use. Rumen liquid must be fresh which implies the existence of animals with fistulas (which are not available to all laboratories) because the activity of the microorganisms is lost or changed during liquid storage. There are many factors that can influence the obtained results such as the variation in the quality of the rumen liquid that can occur due to the species and diet of the animal from which the inoculum is taken, the collection time and to what extent the anaerobic conditions, optimal $\mathrm{pH}$ and temperature are maintained (Jones and Theodorou, 2000; Adesogan, 2002; Lopez, 2005). These disadvantages can be avoided by using exogenous enzymes for incubation of feed that aim to imitate digestive processes in the animal. The use of enzymes as an alternative to a rumen inoculum has the advantage of overcoming the need for fistulated animals and anaerobic procedures, simplifying analytical methodology and eliminating variability in inoculum activity (Lopez, 2005).

Weisberg and Hvelplund (1993) developed in vitro multi-enzymatic method for determining OMD of concentrated feedstuffs that are used in ruminant nutrition. The principle of OMD determination consists primarily in the incubation of a sample in acidic pepsin solution for 24 hours in order to degrade the proteins. The mixture is then heated to $80{ }^{\circ} \mathrm{C}$ in order to inactivate pepsin and create conditions for starch hydrolysis. After rinsing with water, the sample is incubated in a mixture of enzymes, resulting in the degradation of starch and digestible carbohydrates from cell walls. The insoluble residues are washed with warm water and then with acetone for the purpose of extracting the fat. For the calculation of in vitro OMD it is necessary to determine the content of dry matter and ash in the indigestible residue of the sample. Over the years, the use of this method has been confirmed and the prediction of in vivo OMD of straw (Hvelplund et al., 1999), various feedstuffs (Palić and Muller, 2006) and complete mixtures (Palić and Leeuw, 2009), as well as for the calibration of NIR device (Pojić et al., 2008). In aforementioned papers, the multi-enzyme method proved to be equally reliable in predicting in vivo OMD as well as the in vitro method Tilley and Terry (1963). Also, this method is the official method in Denmark for assessing in vivo OMD of concentrated feedstuffs and complete feed (Akerlind et al., 2011) using the formula:

In vivo digestibility $=5.38+0.867 \times$ (in vitro enzyme digestibility (\%))

To the best of our knowledge no research was found where thermally treated samples of feed were analyzed using this in vitro method. Therefore, the aim of the present work was to determine whether this in vitro multi-enzymatic method can be applied for the assessment of the influence of thermal treatments on OMD of feed for ruminants.

\section{MATERIAL AND METHODS}

Corn variety ZP666 grown in Serbia was used in this research. Using computer program "MIXOLINO" complete mixture for dairy cows was formulated with the aforementioned corn as the only grain in the mixture. Composition of complete mixture for dairy cows is presented in Table 1, while Table 2 presents basic chemical composition of corn and complete mixture.

In the first part of the experiment corn was subjected to pelleting, steam flaking, micronization and extrusion. Prior to pelleting and extrusion corn was milled using hammer mill equipped with a $4 \mathrm{~mm}$ sieve, while steam flaking and micronization were conducted on whole corn grain. All samples were conditioned prior to selected thermal treatment except for one (sample MC1, see Table 3). In the second part of the experiment same thermal treatments were applied on complete mixture. Prior to pelleting and extrusion all components of 
complete mixture were milled, then mixed and conditioned. Since the steam flaking and micronization are possible to apply only on whole corn grain, complete mixture was formed of steam flaked or micronized corn and with the addition of the rest of diet components that were previously mixed and pelleted. Applied temperatures during thermal treatments are presented in Table 3.

In vitro OMD of untreated and thermally treated corn and complete mixture was

Table 1.

Composition of complete mixture for dairy cows

\begin{tabular}{lc}
\hline Feedstuff & \% in mixture \\
\hline Corn & 59 \\
Sunflower meal (33\% protein) & 24 \\
Soybean meal (44\% protein) & 13 \\
Limestone & 2 \\
Monocalcium phosphate & 0.9 \\
Feed salt & 0.6 \\
Premix & 0.5 \\
\hline
\end{tabular}

Table 2.

Chemical composition of corn and complete mixture for dairy cows

\begin{tabular}{lcc}
\hline Parameter & Corn & Complete mixture \\
\hline Moisture (\%) & 10.96 & 9.94 \\
Starch (\% DM) & 75.63 & 49.15 \\
Protein (\% DM) & 8.84 & 18.08 \\
Celulose (\% DM) & 3.04 & 4.03 \\
Ash (\% DM) & 1.12 & 6.10 \\
\hline
\end{tabular}

Table 3.

Temperature during pelleting, steam flaking, micronization and extrusion

\begin{tabular}{cccc}
\hline Corn & $\begin{array}{c}\text { Temperature } \\
\text { during thermal } \\
\text { treatment }\end{array}$ & $\begin{array}{c}\text { Complete } \\
\text { mixture }\end{array}$ & $\begin{array}{c}\text { Temperature } \\
\text { during thermal } \\
\text { treatment }\end{array}$ \\
\hline $\mathrm{UC}$ & $\mathrm{I}$ & $\mathrm{UM}$ & $/$ \\
$\mathrm{PC}$ & $61^{\circ} \mathrm{C}$ & $\mathrm{PM}$ & $75^{\circ} \mathrm{C}$ \\
$\mathrm{FC}$ & $85^{\circ} \mathrm{C}$ & $\mathrm{FM}$ & $\mathrm{FC}+$ pelleted other components $\left(80^{\circ} \mathrm{C}\right)$ \\
$\mathrm{MC} 1^{*}$ & $125^{\circ} \mathrm{C}$ & $\mathrm{MM} 1$ & $\mathrm{MC} 1+$ pelleted other components $\left(80^{\circ} \mathrm{C}\right)$ \\
$\mathrm{MC} 2$ & $111^{\circ} \mathrm{C}$ & $\mathrm{MM} 2$ & $\mathrm{MC} 2+$ pelleted other components $\left(80^{\circ} \mathrm{C}\right)$ \\
$\mathrm{MC} 3$ & $125^{\circ} \mathrm{C}$ & $\mathrm{MM}$ & $\mathrm{MC} 3+$ pelleted other components $\left(80^{\circ} \mathrm{C}\right)$ \\
$\mathrm{EC} 1$ & $80^{\circ} \mathrm{C}$ & $\mathrm{EM} 1$ & $80^{\circ} \mathrm{C}$ \\
$\mathrm{EC} 2$ & $95^{\circ} \mathrm{C}$ & $\mathrm{EM} 2$ & $95^{\circ} \mathrm{C}$ \\
$\mathrm{EC} 3$ & $110^{\circ} \mathrm{C}$ & $\mathrm{EM}$ & $110^{\circ} \mathrm{C}$ \\
\hline
\end{tabular}

*sample was not previously conditioned;

UC - untreated corn; PC - pelleted corn; FC - steam flaked corn; MC1-MC3 - micronized corn; EC1-EC3 extruded corn;

UM - untreated mixture; PM - pelleted mixture; FM - steam flaked corn + pelleted other components; MM1-MM3

- micronized corn + pelleted other components; EM1-EM3 - extruded mixture. 
Table 4.

In vitro OMD of corn grain and complete mixture for dairy cows subjected to different thermal treatments

\begin{tabular}{cccc}
\hline Corn & OMD (\%) & Complete mixture & OMD (\%) \\
\hline UC & $91.69 \pm 0,23^{\mathrm{a} *}$ & UM & $93.18 \pm 0.85^{\mathrm{ab}}$ \\
PC & $92.53 \pm 0.76^{\mathrm{ab}}$ & PM & $93.02 \pm 0.51^{\mathrm{ab}}$ \\
FC & $92.08 \pm 0.05^{\mathrm{a}}$ & FM & $92.89 \pm 0.62^{\mathrm{ab}}$ \\
MC1 & $91.54 \pm 0.83^{\mathrm{a}}$ & MM1 & $93.22 \pm 0.52^{\mathrm{ab}}$ \\
MC2 & $91.64 \pm 0.55^{\mathrm{a}}$ & MM2 & $93.09 \pm 0.23^{\mathrm{ab}}$ \\
MC3 & $91.93 \pm 0.44^{\mathrm{a}}$ & MM3 & $92.03 \pm 0.29^{\mathrm{b}}$ \\
EC1 & $92.76 \pm 0.28^{\mathrm{ab}}$ & EM1 & $93.41 \pm 0.69^{\mathrm{a}}$ \\
EC2 & $93.65 \pm 0.27^{\mathrm{b}}$ & EM2 & $93.61 \pm 0.52^{\mathrm{a}}$ \\
EC3 & $92.89 \pm 0.23^{\mathrm{ab}}$ & EM3 & $93.66 \pm 0.47^{\mathrm{a}}$ \\
\hline
\end{tabular}

Results are given as mean \pm standard deviation $(n=3)$;

${ }^{*}$ Column values followed by the same superscript are not significantly different $(p<0.05)$;

UC - untreated corn; PC - pelleted corn; FC - steam flaked corn; MC1-MC3 - micronized corn; EC1-EC3 extruded corn;

UM - untreated mixture; PM - pelleted mixture; FM - steam flaked corn + pelleted other components; MM1-MM3 - micronized corn + pelleted other components; EM1-EM3 - extruded mixture.

\section{RESULTS AND DISCUSSION}

In vitro OMD of corn grain and complete mixture for dairy cows subjected to different thermal treatments is presented in Table 4. OMD of untreated corn was $91.69 \%$ which is in agreement with the results of Aufrere and Michalet-Doreau (1988), Bailoni et al. (2006) and Kokić et al. (2013). The use of formula that calculates in vitro to in vivo OMD (presented in introduction) yields a value of $84.88 \%$ in vivo OMD for sample UC, which is in accordance with the results of Cooper et al. (2002) for dry rolled corn (84.6\%).

In the untreated complete mixture, determined OMD was higher $(93.18 \%)$ in comparison to the untreated corn, probably because soybean meal has higher OMD than corn (Aufrere and Michalet-Doreau, 1988; Kokić et al., 2013). Statistical analysis of the results did not show significant increase in OMD of corn and complete mixture after various thermal treatments compared to the untreated samples; except for the sample EC2. The obtained results are in accordance with the results of other authors who analyzed the effect of thermal treatments on OMD of corn using other in vitro methods (Bailoni et al., 2006; Qiao et al., 2015). Slightly increased OMD of extruded sample EC2 compared to unprocessed corn can be attributed to severe conditions during extrusion like high shear forces and long retention time in extruder barrel that could have led to more complete denaturation of proteins and gelatinization of starch.

Based on the results of Qiao et al. (2015) steam flaking did not lead to a statistically significant increase in maize and wheat OMD (determined by the gas production technique), while in rice, which has lower OMD than corn and wheat, the increase in OMD was significant $(p<0.05)$. Bailoni et al. (2006) also reported that steam flaking and extrusion did not increase in vitro OMD of corn (determined by pepsin cellulase technique), while the increase was recorded for barley and oats.

On the other hand, Cooper et al. (2002) reported that dry rolled corn OMD determined in vivo was $84.6 \%$, and that it was increased after steam flaking to $88.1 \%$. Increase of in vivo OMD of thermally treated corn published by Cooper et al. (2002) was probably possible to record because of the application of the in vivo method, which is the reference method for OMD.

Based on the obtained results and available literature data it can be concluded that various in vitro methods are not able to detect the change in OMD after thermal treatments of samples that has high digestibility (such as corn) and that in such ca- 
ses other methods should be used, preferably in vivo method.

\section{CONCLUSIONS}

According to the results obtained in this study it can be concluded that applied in vitro method is not able to detect the change in OMD of corn after thermal treatments, which can be explained by high digestibility of corn itself (exceeds 90\%). In future research, samples with lower OMD should be analyzed, such as sorghum, oats and barley, in order to determine whether this in vitro multi-enzymatic method can be used for the assessment of the influence of thermal treatments on OMD of feed for ruminants.

\section{ACKNOWLEDGEMENTS}

This paper is a result of the research within the project III46012 financed by the Ministry of Education, Science and Technological Development, Republic of Serbia.

\section{REFERENCES}

1. Adesogan, A.T. (2002). What are feeds worth?: A critical evaluation of selected nutritive value methods. $13^{\text {th }}$ Annual Florida Ruminant Nutrition Symposium, Proceedings, pp. 33-47.

2. Akerlind, M., Weisbjerg, M., Eriksson, T., Togersen, R., Uden, P., Olafsson, B., Harstad, O., Volden, H. (2011). Feed analysis and digestion methods. In Norfor - the Nordic feed evaluation system. Ed. H. Volden, Wageningen Academic Publishers, Wageningen, The Netherlands, pp. 41-54.

3. Aufrere, J., Michalet-Doreau, B. (1988). Comparison of methods for predicting digestibility of feeds. Animal Feed Science and Technology, 20, 203-218.

4. Bailoni, L., Mantovani, R., Pagnin, G., Schiavon, S. (2006). Effects of physical treatments on the resistant starch content and in vitro organic matter digestibility of different cereals in horses. Livestock Science, 100, 14-17.

5. Cooper, R., Milton, C., Klopfenstein, T.J., Scott, T., Wilson, C., Mass, R. (2002). Effect of corn processing on starch digestion and bacterial crude protein flow in finishing cattle. Journal of Animal Science, 80, 797-804.

6. Getachew, G., Blümmel, M., Makkar, H.P.S., Becker, K. (1998). In vitro gas measuring techniques for assessment of nutritional quality of feeds: a review. Animal Feed Science and Technology, 72, 261-281.

7. Gosselink, J.M.J., Dulphy, J.P., Poncet, C., Jailler, M., Tamminga, S., Cone, J.W. (2004). Prediction of forage digestibility in ruminants using in situ and in vitro techniques. Animal Feed Science and Technology, 115, 227-246.

8. Hvelplund, T., Riis Weisbjeng, M., Soegaard, K. (1999). Use of in vitro digestibility methods to estimate in vivo digestibility of straws. $26^{\text {th }}$ Scientific Conference of the Tanzania Society of Animal Production, Proceedings, pp. 70-79.

9. Jones, D.I.H., Theodorou, M.K. (2000). Enzyme techniques for estimating digestibility. In Forage evaluation in ruminant nutrition. Eds. D.I. Givens, E. Owen, R.F.E. Axford, H.M. Omed, CABI Publishing, Oxon, UK, pp. 155-173.

10. Kokić, B., Palić, D., Ivanov, D., Lević, J., Spasevski, N., Đuragić, O., Čabarkapa, I. (2013). Modification of in vitro multi-enzymatic method for determining the organic matter digestibility of feeds. Agro FOOD Industry Hi Tech, 24, 5961.

11. Lopez, S. (2005). In vitro and in situ techniques for estimating digestibility. In Quantitative Aspects of Ruminant Digestion and Metabolism. Eds. J. Dijkstra, J.M. Forbes, J. France, $2^{\text {nd }}$ edn. CAB International, Wallingford, UK, pp. 87121.

12. Menke, K.H., Steingass, H. (1988). Estimation of the energetic feed value obtained from chemical analysis and in vitro gas production using rumen fluid. Animal Research and Development, 28, 7-55.

13. Palić, D., Leeuw, K.-J. (2009). Comparison of three in vitro methods for determining and predicting the organic matter digestibility of complete diets for ruminants. Acta periodica technologica, 40, 79-86.

14. Palić, D., Muller, H. (2006). Prediction of the in vivo organic matter digestibility of feedstuffs for ruminants using in vitro techniques. Savremena poljoprivreda, 55, 127-132.

15. Pojić, M., Palić, D., Mastilović, J., Janić-Hajnal, E. (2008). The introduction of a method for determination of organic matter digestibility in feeds into routine laboratory practice. Food Processing, Quality and Safety, 35, 151-155.

16. Qiao, F.-Q., Wang, F., Ren, L.-P., Zhou, Z.-M., Meng, Q.-X., Bao, Y.-H. (2015). Effect of steam-flaking on chemical compositions, starch gelatinization, in vitro fermentability, and energetic values of maize, wheat and rice. Journal of Integrative Agriculture, 14, 949-955.

17. Tilley, J.M.A., Terry, R.A. (1963). A two-stage technique for the in vitro digestion of forage crops. Grass and Forage Science, 18, 104-111.

18. Weisberg, R., Hvelplund, T. (1993). Estimation of net energy content in feeds for cattle, Report No. 3/1993, National Institute of Animal Science, Tjele, Denmark. 


\title{
МОГУЋНОСТ ПРИМЕНЕ ИН ВИТРО МУЛТИЕНЗИМСКЕ МЕТОДЕ ЗА ПРОЦЕНУ УТИЦАЈА ТЕРМИЧКИХ ТРЕТМАНА НА СВАРЉИВОСТ ОРГАНСКЕ МАТЕРИЈЕ ХРАНЕ ЗА ПРЕЖИВАРЕ
}

\author{
Бојана М. Кокић${ }^{\star 1}$, Љубица П. Докић ${ }^{2}$ Радмило Р. Чоловић ${ }^{1}$, Војислав В. Бањац ${ }^{1}$, Раде Д.
} Јовановић ${ }^{3}$, Сања Ј. Поповић ${ }^{1}$, Јасмина М. Лазаревић ${ }^{1}$

${ }^{1}$ Универзитет у Новом Саду, Институт за прехрамбене технологије у Новом Саду, 21000 Нови Сад, Булевар цара Лазара 1, Србија

${ }^{2}$ Универзитет у Новом Саду, Технолошки фракултет, 21000 Нови Сад, Булевар цара Лазара 1 , Србија

${ }^{3}$ Институт за примену науке у пољопривреди, 11000 Београд, Булевар деспота Стефрана 68б, Србија

Сажетак: Ин витро мулти-ензимска метода је двостепена процедура која користи егзогене ензиме за инкубацију хране за животиње која има за циљ имитирање процеса варења код животиња. Користи се за одређивање сварљивости органске материје (СОМ) различитих хранива и комплетних смеша које се користе у исхрани преживара. Циљ овог рада био је да се утврди да ли се ова ин витро мулти-ензимска метода може применити за процену утицаја термичких третмана на СОМ хране за преживаре. Узорци кукуруза и комплетна смеша за краве (на бази кукуруза) су пелетирани, парно фрлекичани, микронизирани и екструдирани. Статистичка анализа резултата није показала значајно повећање СОМ кукуруза и комплетне смеше након различитих термичких третмана у поређењу са нетретираним узорцима, што се може објаснити високом сварљивости самог кукуруза (преко 90\%). На основу добијених резултата може се закључити да примењена ин витро метода није погодна за процену утицаја термичких третмана на СОМ кукуруза и смеша на бази кукуруза, док се будућа истраживања требају проширити на анализу узорака са нижом СОМ, као што су сирак, овас и јечам. третман

Кључне речи: сварљивост органске материје, преживари, кукуруз, термички

Received: 21 March 2018

Received in revised form: 26 April 2018

Accepted: 8 May 2018 